\title{
La lectura bajo un enfoque constructivista
}

A lo largo del tiempo, investigadores y expertos en el área del constructivismo se han aproximado al estudio de la lectura utilizando distintos enfoques. Éstos han sido influidos por diferentes corrientes psicológicas y por las nuevas teorías sobre la forma en que se da el proceso de enseñanza y aprendizaje. Algunas de ellas son las que se enfocan al estudio del fenómeno lector que recibe el nombre de modelos de lectura. Según Del Campo y López Polanco, los modelos de lectura deben "especificar las variables que afectan el proceso lector y dar una idea del funcionamiento cognitivo durante la realización de la misma" (Del Campo y López Polanco, 1990: 24).

Entre los modelos de lectura que los autores mencionados proponen, se destacan los siguientes:

1. Modelos de procesamiento de la información. Comparten la postura que concibe a la lectura como un proceso en etapas en la que se parte de la percepción visual del texto para terminar con la construcción del significado o con otra respuesta por partes del lector. Ejemplos de éstos son los modelos bottom up o ascendentes, que consideran la lectura como un proceso conciso y detallado de percepción secuencial y de identificación de letras y palabras que forman frases; el papel del texto se impone al lector, al que se le otorga la función de mero descodificador. Desde esta perspectiva, los problemas de lectura se consideran simplemente problemas de descodificación. El significado procede, en exclusiva, de la letra impresa, secuenciales y outside-out.

2. Modelos de análisis por síntesis. Según estos modelos, el lector hace uso de sus experiencias y conocimientos previos para formular hipótesis sobre el texto que se lee. Mientras lee, el lector refutará o confirmará las hipótesis que formuló anteriormente. Algunos ejemplos son los modelos top-down o descendentes, que dan prioridad a la capacidad interpretativa del lector hasta el punto en que leer implica el uso parcial de pistas mínimas de la lengua, seleccionadas del continuo lingüístico, según las expectativas del lector. La lectura se convierte en lo que Goodman (1976) llamó "juego de adivinación". De este modo se deja de prestar atención al texto en sí mismo. 
3. Modelos de mediación fonológica. En éste, el lector descifra primero el código fonológico contenido en las letras del texto, para después extraerle su significado.

4. Modelos interactivos. Este tipo de modelos es el que más recientemente ha surgido gracias a las últimas investigaciones hechas respecto al tema. Estos modelos consideran importantes para la comprensión del texto tanto los procesos mecánicos inferiores (el reconocimiento de letras y fonemas) como los procesos intelectuales superiores (la inferencia, la creación de hipótesis, etcétera). La lectura se concibe desde esta nueva perspectiva como un proceso de interacción o de influencia mutua entre el texto y el lector, por un lado; y entre los dos modos de procesar-bottom up y top down-que intervienen en el proceso, por otro. En otras palabras, en este modelo es tan importante el texto como el conocimiento previo que posee el lector.

En este punto, es importante señalar que dichos modelos van enfocados a la base teóri- ca de la postura constructivista, es decir, a los modelos de análisis por síntesis, ya que parecen más sólida teórica y empíricamente y van de acuerdo con nuestra filosofía personal del aprendizaje: simplemente, resulta obvio que la mejor manera de aprender a hacer las cosas, es haciéndolas. Para ello, la corriente constructivista basada en las teorías de Vigotsky, Piaget y Ausubel, sostiene que la persona humana aprende construyendo una representación de los objetos a conocer haciendo uso de sus esquemas cognitivos, es decir, nos acercamos a lo que queremos aprender con aquellas estructuras que ya poseemos, adaptándolas y adquiriendo nuevas en el proceso.

En palabras de Fons: "aprender significativamente no es acumular conocimientos, sino establecer relaciones de forma no arbitraria y sustantiva entre lo que ya se sabe y lo que se quiere aprender" (Fons, 2004: 25). Sin embargo, para que se dé un aprendizaje significativo algunas condiciones son necesarias, Antúnez (1991, citado en Fons, 2004: 26) señala las siguientes: 
- Significación lógica y coherente: el objeto de aprendizaje debe poseer coherencia y claridad.

- Significación psicológica: para que el aprendizaje ocurra, el sujeto debe poseer conocimientos previos relacionados con el objeto de aprendizaje en cuestión. Además, para que se realice una conexión apropiada entre el nuevo conocimiento y el anterior, el sujeto debe poseer un suficiente grado de desarrollo cognitivo.

- Actividad mental del alumnado: la facultad de aprender radica en el alumno que quiere hacerlo, no en el docente que le enseña.

- Actitud favorable: el alumno o sujeto que va a aprender algo debe poseer una actitud positiva hacia el proceso y el objeto de aprendizaje; la motivación juega un papel muy trascendente en este aspecto.

- Memorización comprensiva: el aprendizaje significativo debe integrarse a la memoria del sujeto que aprende. Sin embargo, esta memorización no debe ser mecánica sino basada en una comprensión integral del objeto de conocimientos.

Los postulados teóricos mencionados han sido también aplicados al estudio de la lectura desde una perspectiva constructivista. Gómez Palacios la anunció en los siguientes términos: "Tradicionalmente se consideró a la lectura como el rescate del significado expresado en el texto, lo que dejaba para el lector una posición receptiva, sin que sus expectativas intervinieran al leer y sin la posibilidad de llegar a más de un significado. Con base a [sic] los principios de la teoría constructivista, se reconoce hoy a la lectura como un proceso interactivo entre pensamiento y lenguaje, y a la compresión como la construcción del significado del texto, según los conocimientos y experiencias del lector" (Gómez Palacios, 1997: 19); asimismo, el autor declara que la lectura puede ser definida como "un proceso constructivo" en el cual el significado no es algo intrínsecamente perteneciente al texto o determinado en su totalidad, sino que se construye mediante un proceso de transacción flexible en el que el lector le otorga sentido al texto. Así pues, ésta es una postura que por fin brinda al que lee un rol activo en el proceso lector y no lo reduce al simple papel de receptor y decodificador de información, sino que toma en cuenta sus experiencias, expectativas y capacidades.

La teoría constructivista considera que la lectura es:

- Un proceso activo: porque el lector es responsable de la construcción de significado en un texto, involucrando sus expectativas y conocimientos previos.

- La consecuencia de un objetivo: puesto que se lee para alcanzar alguna finalidad y ésta determina las estrategias a seguir y la interpretación que se hace del texto.

- Un proceso de interacción: que se da entre lector y texto. El primero relaciona lo que ya sabía con lo que encuentra en el texto, modifica sus esquemas cognitivos previos y desarrolla algunos nuevos.

- Un proceso de predicción e indiferencia continua: debido a que el lector conjetura o formula hipótesis sobre el contenido del texto y éstas se confirman o refutan al leerlo. (Fons, 2004: 21-22). 


\section{Conclusiones}

Se puede concluir que el fenómeno lector posee una importancia educativa muy trascendente, por lo que ha sido objeto de estudio y debate constante. Asimismo, se puede afirmar que es la lectura un proceso de considerable complejidad, del cual toman parte muchos elementos propios y ajenos a la persona que lo llevó a cabo, tales como procesos cognitivos o las condiciones ambientales en que se realiza. Estos factores deben ser considerados al momento de realizar cualquier tipo de investigación al respecto.

De igual forma, existen diversas características que hacen de la lectura un tipo de lectura especial y diferente, ya que en ocasiones requiere el uso de estrategias, habilidades y conocimientos más complejos. En consecuencia, es lógico pensar que un estudiante que cuente con una formación lectora apropiada desde temprana edad se encontrará en condiciones más favorables para aprovechar al máximo sus estudios.

Por último, el modelo de lectura constructivista resulta conveniente para acercarse al estudio de este fenómeno, pues se basa en el entendimiento de los procesos cognitivos internos del ser humano y le brinda al lector un papel activo en el proceso de comprensión de un texto.

\section{Fuentes de consulta}

Carrasco Dávila. A.F. (2003). La lectura en México. Consultada en enero de 2012, disponible en: www.redespecialweb.org/ponencias5/originales $5 /$ alan $\% 202 \% 20$ (lectura).rtf.

Cassany, D.; Luna, M. y Sanz, G. (1997). Enseñar Lengua. Barcelona: Graó.

Chávez Méndez, M.G. (2002). Práctica de la lectura en México y el libro como producto cultural. México: Red AlTexto.

Del Campo, A. y López Polanco, G. (1990). El estudio y la lectura: consejo y orientación psicoeducativa para mejorar la habilidad lectora en universitarios. España: Dykinson.

Fons Esteve, M. (2004). Leer y escribir para vivir. Alfabetización inicial y uso real de la lengua escrita. España: Graó.

Gutiérrez, A. (1997). Educación multimedia y nuevas tecnologías. Madrid: Ediciones de la Torre.

Gómez Palacios, M. (1997). La lectura en la escuela, México: SEP.

Goodman, K.S. (1976). Reading: A psycholinguistic guessing game. En H. Singer y R.B. Ruddell (Eds.), Theoretical models and processes of reading. Newark: International Reading Association.

Melvin H., M. (1997). Proceso de aprendizaje. México: Trillas.

Milla Lozano, F. (2001). Actividades creativas para la lecto-escritura. México: Alfaomega.

Neus, S. (2006). Aprender comunicación digital. Barcelona: Paidós.

Ollivier, B. (2001). Internet, multimedios. ¿Qué cambia en realidad? México: ILCE. 